\title{
First report of the brown shrimp Penaeus aztecus Ives, 1891 (Crustacea, Decapoda, Penaeidae) in the Tyrrhenian Sea
}

\author{
MARCO CRUSCANTI ${ }^{1}$, GIANNA INNOCENTI ${ }^{1}$, JAIME ALVARADO BREMER ${ }^{2,3}$ AND BELLA S. GALIL ${ }^{4}$ \\ ${ }^{1}$ Museo di Storia Naturale, Università di Firenze, via Romana 17, 50125 Firenze, Italy, ${ }^{2}$ Department of Marine Biology, Texas A\&M \\ University at Galveston, P.O. Box 1675, Galveston, Texas 77553, USA, ${ }^{3}$ Department of Wildlife and Fisheries Science, Texas A\&M \\ University, College Station, Texas, 77843-2258, USA, ${ }^{4}$ National Institute of Oceanography, Israel Oceanographic \& Limnological \\ Research, P.O. Box 8030, Haifa 31080, Israel
}

\begin{abstract}
Two specimens of the penaeid shrimp Penaeus aztecus, a West Atlantic species, were collected off Castiglione della Pescaia, Tyrrhenian coast of Italy. The species identity was confirmed based on morphological characters and by sequencing 510 nucleotides of the mtDNA 16sRNA gene. This alien species has been previously recorded off Turkey, Greece and Montenegro.
\end{abstract}

Keywords: Penaeus aztecus, Tyrrhenian Sea, distribution records, new records

Submitted 3 March 2015; accepted 14 May 2015

\section{INTRロDUCTIDN}

Of the 14 penaeid prawn species recorded in the Mediterranean Sea (Galil et al., 2002 ; Galil et al., 2015), eight are considered to have been introduced through the Suez Canal - Metapenaeopsis aegyptia Galil \& Golani, 1990; Metapenaeopsis mogiensis consobrina (Nobili, 1904); Metapenaeus monoceros (Fabricius, 1798); Metapenaeus stebbingi Nobili, 1904; Penaeus hathor (Burkenroad, 1959); Penaeus pulchricaudatus Stebbing, 1914; Penaeus semisulcatus De Haan, 1844, Trachysalambria palaestinensis (Steinitz, 1932); one species - Penaeus japonicus Spence Bate, 1888 - was officially introduced for mariculture (Tournier, 1972); and five species, all of commercial interest and newly recorded in the past decade Metapenaeus affinis (H. Milne Edwards, 1837); Penaeus aztecus Ives, 1891; Penaeus merguiensis De Man, 1888; Penaeus subtilis (Pérez Farfante, 1967); Rimapenaeus similis (Smith, 1885) - are likely illegal introductions.

The first record for Penaeus aztecus in the Mediterranean Sea dates to December 2009, when it was collected in Antalya, Turkey (Deval et al., 2010, as Farfantepenaeus aztecus). Soon after, it was collected from trawl catches along the Mediterranean coast of Turkey from Iskenderun to Finike (Gökoğlu \& Ovzarol, 2013; Özvarol \& Gökoğlu, 2014). Subsequently, it was reported from the Aegean Sea (Nikolopoulou et al., 2013; Kevrekidis, 2014; Kondylatos \& Corsini-Foka, 2015; Minos et al., 2015), off Corfu, the Ionian Sea (Kapiris \& Apostolidis, 2014) and Montenegro, Adriatic Sea (Marković et al., 2014). We report its occurrence in the Tyrrhenian Sea.

Corresponding author:

G. Innocenti

Email: gianna.innocenti@unifi.it

\section{MATERIAL AND METHDDS}

On 6 August 2014, a single female specimen was found in the haul of $\mathrm{M} / \mathrm{V}$ 'Jolly', whilst trawling for red mullets, pink shrimps and karamote prawns (Melicertus kerathurus) on muddy bottoms near Castiglione della Pescaia $\left(42^{\circ} 42.258^{\prime} \mathrm{N}\right.$ $010^{\circ} 53.716^{\prime} \mathrm{E}$ ) at a depth of $70 \mathrm{~m}$. The specimen (total length estimated at $180 \mathrm{~mm}$ ) was photographed, though not preserved. On 4 November 2014, a single male specimen was collected by the same vessel in Follonica Gulf $\left(42^{\circ} 51.146^{\prime} \mathrm{N} 10^{\circ} 39.000^{\prime} \mathrm{E}\right)$ on a muddy bottom, at a depth of $40 \mathrm{~m}$. This specimen (total length $135 \mathrm{~mm}$ ) was photographed and deposited in the crustacean collection of the Natural History Museum of Florence University (collection number MZUF 4303). A pereiopod was detached for molecular analysis.

A small $\left(<_{1} \mathrm{~mm}\right)$ piece of the pereiopod was cut with sterilized scissors near the proximal end of the articulation and used as a DNA source. The total genomic DNA was isolated using a Zymo Universal G-DNA kit (Zymo Research, Irvine, California). The digest was spun for $30 \mathrm{~s}$ at $14,000 \mathrm{~g}$ to pellet the undigested exoskeleton and $1 \mu \mathrm{l}$ of the supernatant was used as a PCR template. A segment about 550 base pairs (bp) long of the 16SrRNA (16S) mitochondrial gene was PCR amplified using primers $16 \mathrm{SarL}$ and $16 \mathrm{SbrH}$ (Palumbi et al., 1991) in $12.5 \mu \mathrm{l}$ reactions volumes containing $10 \mathrm{ng}$ of genomic DNA, $1 \mathrm{X}$ EconoTaq PLUS Green Master Mix (Lucigen Corporation, Middleton, Wisconsin) and 5 pmol of each primer. PCR was performed on an Eppendorf Mastercycler Gradient (Eppendorf, Hamburg, Germany) with thermocycling parameters consisting of an initial denaturation step at $94^{\circ} \mathrm{C}$ for $4 \mathrm{~min}$ followed by 36 cycles at $94^{\circ} \mathrm{C}$ for $30 \mathrm{~s}, 55^{\circ} \mathrm{C}$ for $45 \mathrm{~s}, 65^{\circ} \mathrm{C}$ for 1 min and a final extension at $65^{\circ} \mathrm{C}$ for $3 \mathrm{~min}$. The quality of amplified product was verified by agarose gel electrophoresis and a negative control was included to screen for cross-contamination. The amplicon 
was diluted 1:10, and $2 \mu \mathrm{l}$ of this dilution were used as template in sequencing reactions performed in both directions in $10 \mu \mathrm{l}$ volumes that contained $10 \mathrm{pmol}$ of primer and the BigDye $^{\mathrm{TM}}$ Terminator Cycle sequencing Ready Reaction Kit (Applied Biosystems, Foster City, California, USA) as recommended by the manufacturer and the STeP fast cycling protocol (Platt et al., 2007). Unincorporated dye terminators and primers were removed using ZR DNA Sequencing Clean-up $\mathrm{Kit}^{\mathrm{TM}}$ (Zymo Research) and clean sequencing reactions were eluted in $20 \mu \mathrm{l}$ of $\mathrm{Hi}$-Di Formamide (Life Technologies, Grand Island, NY) and then loaded on an ABI 3130 Genetic Analyser (Applied Biosystems) to determine the DNA sequence. The resulting $16 \mathrm{~S}$ chromatogram of the Tyrrhenian Sea specimen was visually inspected in Geneious Ver. 7.1.7 (Biomatters Ltd., Auckland, NZ) and the sequence was submitted to GenBank using the program Blastn (GenBank Accession \# pending). The program ClustalW (Larkin et al., 2007) was invoked in Geneious using default settings to align the $16 \mathrm{~S}$ sequence of the Italian specimen against the orthologous of other penaeid shrimp with the GenBank accession numbers: $\mathrm{AF} 279811-\mathrm{AF} 279812, \mathrm{AF} 279818, \mathrm{AF} 192051-\mathrm{AF} 192056$, AF192071, AF192087-AF192089, AF255054-AF255057, AJ297970-AJ297971, AJ132780, A40446914 (Maggioni et al., 2001) and HMo14401-HMo14412 (Alvarado Bremer \& Ditty, 2010). The resulting alignment file was used in MEGA to reconstruct the phenetic relationship of the Italian specimen against the reference sequences using neighbour joining (NJ) based on a matrix of Tamura-Nei distances with branch support, obtained using non-parametric bootstrapping (Felsenstein, 1985) involving 1000 pseudo-replicates.

\section{RESULTS AND DISCUSSION}

The male specimen was identified following Pérez-Farfante (1988: 12, Figure 17): the adrostral sulcus long, almost reaching posterior margin of carapace, median sulcus long, deep along entire length; rostrum with three ventral teeth; cheliped coxae unarmed; telson with deep median sulcus, lateral movable spines; ventral costa of petasma tapering distally, arched, bearing elongate patch of closely set small teeth were noted. After inspection, $510 \mathrm{bp}$ of high quality $(\mathrm{QV}>20)$ sequence of the mtDNA $16 \mathrm{~s}$ rRNA gene were determined for a specimen identified, based on morphological characters, as Penaeus aztecus. The submission of this sequence to GenBank returned a perfect match (100\%) against reference sequences of $16 \mathrm{~S}$ for that species (Maggioni et al., 2001; Alvarado Bremer \& Ditty, 2010). Phylogenetic inference using NJ based on the analysis of 467 bp of sequence unequivocally identifies this specimen as Penaeus aztecus (bootstrap values $=100 \%$, which it turn are readily differentiated from other penaeid shrimp (Figure 1).

Penaeus aztecus is native to the Western Atlantic, from Massachusetts, USA to Yucatan, Mexico. It occurs in the circalittoral, commonly on bottoms less than $50 \mathrm{~m}$ deep, but occasionally is found at greater depths. The young are found

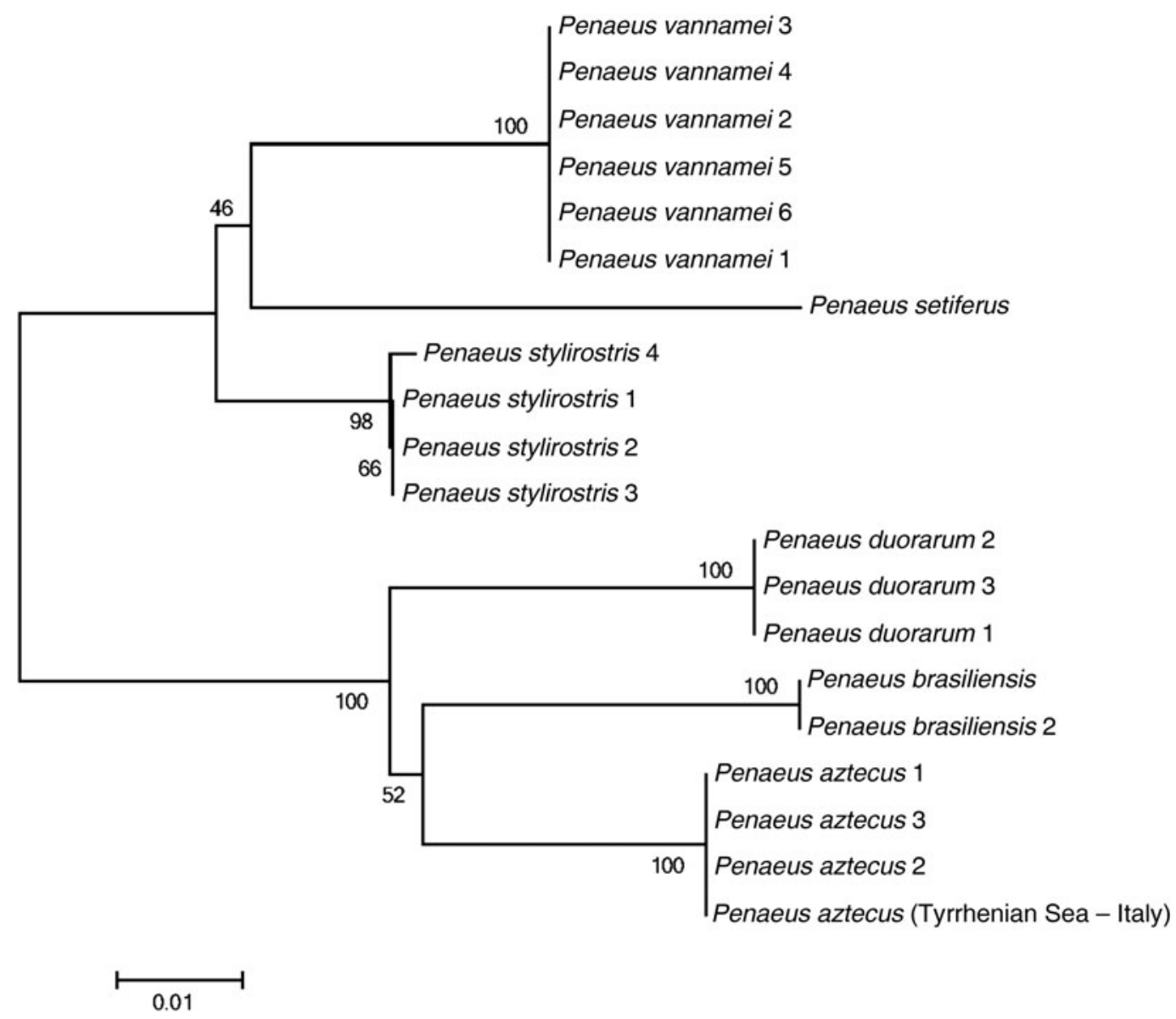

Fig. 1. NJ consensus gene tree based on the analysis of $16 \mathrm{~S}$ sequences depicting the relationship of the Tyrrhenian specimen of Penaeus aztecus against the published sequences of other Penaeid shrimp species available in GenBank (see Materials and Methods). 


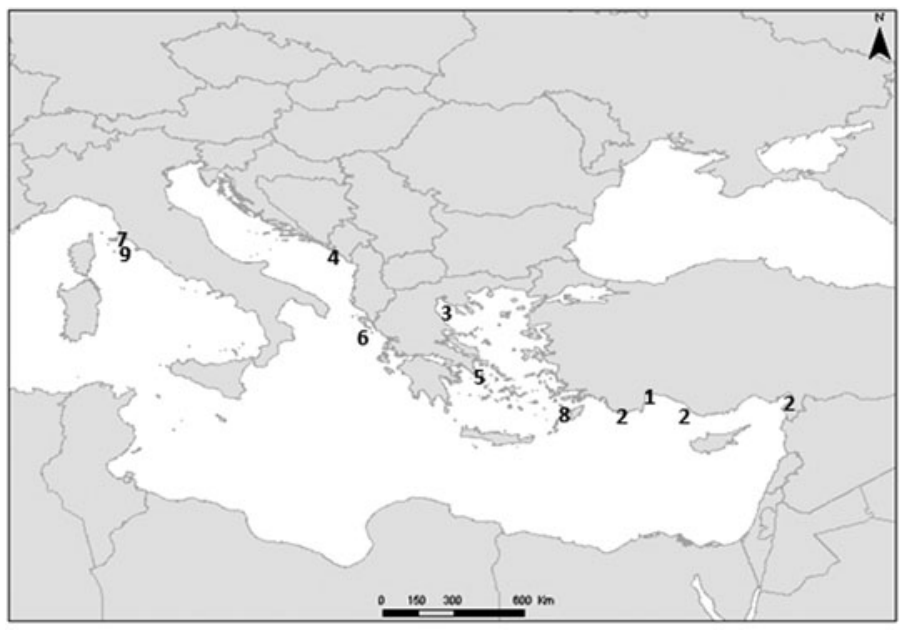

1: December 2010, Antalya, Turkey

(Deval et al., 2010)

2: June 2011-September 2013, from İskenderun to

Finike, Turkey (Gökoğlu \& Ovzarol, 2013)

3: January 2012-September 2013, Thermaikos Gulf, Greece (Nikolopoulou et al., 2013; Kevrekidis, 2014)

4: September 2013, Boka Kotorska Bay, Montenegro

(Marković et al., 2014)

5: November 2013, Argolikos Gulf, Greece

(Minos et al., 2015)

6: November 2013, Korfu Island, Greece

(Kapiris et al., 2014)

7: August 2014, off Castiglione della Pescaia, Italy

(present paper)

8: November 2014, Chalki Island, Greece (Kondylatos

\& Corsini-Foka, 2015)

9: November 2014, off Follonica, Italy (present paper)

Fig. 2. Records of Penaeus aztecus along the Eastern and Central Mediterranean Sea, in chronological order.

in lagoons or estuaries, but adults migrate seawards. It is a commercially important species: annual landings are estimated at 50,000 tons (NOAA, 2013). In the Mediterranean Sea, it has been recorded in lagoons, estuaries and the continental shelf ( 5 to $150 \mathrm{~m}$ ), on sandy, muddy or mixed bottoms (Gökoglu \& Özvarol, 2013) (Figure 2).

Deval et al. (2010) and Kevrekidis (2014) consider ballast waters as the most likely vector for the introduction of Penaeus aztecus in the eastern Mediterranean. Yet, the arrival of five commercially important prawns in quick succession within the past decade raises a suspicion of direct human introduction, particularly as these species have been found in the vicinity of fish and shellfish farms. The bilaterally ablated female banana prawn, Penaeus merguiensis, collected in the Bay of Iskenderun, Turkey, in 2006, is certainly an escape or an inadvertent release from an aquaculture facility, since unilateral and bilateral eyestalk ablation is commonly used in aquaculture for inducing maturation of gonads (Özcan et al., 2006). Thermaikos and Argolikos gulfs are used for fish and shellfish farming, as well as the area along the Castiglione della Pescaia and Follonica coast, Tyrrhenian coast of Italy, where the reported specimens were collected. Mediterranean countries have been notoriously insouciant about biosecurity hazards relating to the movement of stock, feed and equipment that may result in the introduction of marine species (CIESM, 2007); e.g. the southern flatfish, Paralichthys lethostigma Jordan and Gilbert, 1884, was introduced to Israel in 2001 and reared in inland closed systems in order to assess its suitability for aquaculture. According to Golani et al. (2015), 'all adults and juveniles died and the enterprise was closed', yet an adult individual was collected off shore five years later.

The facility with which international transfer via transboundary trade in live prawns is evinced by cases of White Spot Disease in Italian shrimp farm stocked with infected shrimps originating in Turkey (Stentiford \& Lightner, 2011). As in the case of the clandestine importation of Penaeus pulchricaudatus from Turkey into Italy, and Penaeus merguiensis into Turkey (Özcan et al., 2006), no reporting has been made to the Competent Authorities by the industry of importation of Penaeus aztecus. Kevrekidis (2014) related the potential impacts if the population of Penaeus aztecus increases to the point where it competes with the commercially important native prawn Melicertus kerathurus. It seems that, despite directives and regulations, significant biosecurity gaps still exist as concerns the movement of commercially valuable species across international borders and possible consequences once they are released into natural habitats.

\section{ACKNDWLEDGEMENT}

The authors thank Alessandro Taiti, who brought his unusual catch to our attention. This research received no specific grant from any funding agency, commercial or not-for-profit sectors.

\section{REFERENCES}

Alvarado Bremer J.R., Ditty J.G., Turner J.S. and Saxton B.L. (2010) Molecular species identification of commercially important penaeid shrimp from the Gulf of Mexico using a multiplex haplotype-specific PCR assay. Biochemical Systematics and Ecology 38, 715-721.

CIESM (2007) Impact of mariculture on coastal ecosystems. In Briand F. (ed.) CIESM Workshop Monographs no 32. Monaco : CIESM Publisher, pp. 1-120. Available at: www.ciesm.org/online/monographs/lisboa07.pdf.

Deval M.C., Kaya Y., Güven O., Gökoğlu M. and Froglia C. (2010) An unexpected find of the western Atlantic shrimp, Farfantepenaeus aztecus (Ives, 1891) (Decapoda, Penaeidea) in Antalya Bay, eastern Mediterranean Sea. Crustaceana 83, 1531-1537.

Felsenstein J. (1985) Confidence limits on phylogenies: an approach using the bootstrap. Evolution 39, 783-791.

Galil B.S., Froglia C. and Noel P. (2002) Crustaceans: decapods and stomatopods. In Briand F. (ed.) CIESM Atlas of Exotic Species in the Mediterranean, Vol. 2. Monaco: CIESM Publishers, pp. 1-192.

Galil B.S., Froglia C. and Noel P. (2015) Looking back, looking ahead: the CIESM Atlas, Crustaceans. Management of Biological Invasions 6. Available at: http://www.reabic.net/journals/mbi/2015/2/MBI_2015_ Galil_etal_correctedproof.pdf and http://www.reabic.net/journals/mbi/ 2015/Issue2.aspx.

Gökoğlu M. and Ovzarol Y. (2013) Biogeographic expansion of Farfantepenaeus aztecus (Ives, 1891) (Decapoda, Penaeidea) in the eastern Mediterranean, pp. 475-476. In Bilecenoglu M., Alfaya J.E.F., Azzurro E., Baldacconi R., Boyaci Y.Ö., Circosta V., 
Compagno L.J.V., Coppola F., Deidun A., Durgham H., Durucan F., Ergüden D., Fernández-Álvarez F.Á., Gianguzza P., Giglio G., Gökoğlu M., Gürlek M., Ikhtiyar S., Kabasakal H., Karachle P.K., Katsanevakis S., Koutsogiannopoulos D., Lanfranco E., Micarelli P., Özvarol Y., Pena-Rivas L., Poursanidis D., Saliba J., Sperone E., Tibullo D., Tiralongo F., Tripepi S., Turan C., Vella P., Yokeş M.B. and Zava B. (2013) New Mediterranean Marine biodiversity records (December, 2013). Mediterranean Marine Science 14, 463-480.

Golani D., Sonin O. and Rubinstein G. (2015) Records of Paralichthys lethostigma and Sciaenops ocellatus in the Mediterranean and Channa micropeltes in Lake Kinneret (Sea of Galilee), Israel. Marine Biodiversity Records 8, e39, doi: 10.1017/S1755267215000081.

Kapiris K. and Apostolidis C. (2014) Farfantepenaeus aztecus: a new alien decapod in the Ionian Sea, p. 209. In Kapiris K., Apostolidis C., Baldacconi R., Başusta N., Bilecenoglu M., Bitar G., Bobori D.C., Boyaci Y.Ö., Dimitriadis C., Djurović M., Dulčić J., Durucan F., Gerovasileiou V., Gökoğlu M., Koutsoubas D., Lefkaditou E., Lipej L., Marković O., Mavrič B., Özvarol Y., Pesic V., Petriki O., Siapatis A., Sini M., Tibullo D. and Tiralongo F. (2014) New Mediterranean Marine biodiversity records (April, 2014). Mediterranean Marine Science 15, 198-212.

Kevrekidis K. (2014) The occurrence of the Atlantic penaeid prawn Farfantepenaeus aztecus (Ives, 1891) in the Thermaikos Gulf (Aegean Sea, Eastern Mediterranean): considerations on the potential establishment and impact on the autochthonous Melicertus kerathurus (Forskål, 1775). Crustaceana 87, 1606-1619.

Kondylatos G. and Corsini-Foka M. (2015) First record of Penaeus aztecus Ives, 1891 (Crustacea, Decapoda) and Melibe viridis (Kelaart, 1858) (Gastropoda, Nudibranchia) in the southeastern Aegean Sea (Greece). In Zenetos A., Akel E.H.Kh., Apostolidis C., Bilecenoglu M., Bitar G., Buchet V., Chalari N., Corsini-Foka M., Crocetta F., Dogrammatzi A., Drakulić M., Fanelli G., Giglio G., Imsiridou A., Kapiris K., Pkarachle P.K., Kavadas S., Kondylatos G., Lefkaditou E., Lipej L., Mavrič B., Minos G., Moussa R., Pancucci-Papadopoulou M.A., Prato E., Renda W., Ríos N., Rizkalla S.I., Russo F., Servonnat M., Siapatis A., Sperone E., Theodorou J.A., Tiralongo F. and Tzovenis I. (2015) New Mediterranean Marine biodiversity records (April, 2015). Mediterranean Marine Science 16, 266-282.

Larkin M.A., Blackshields G., Brown N.P., Chenna R., McGettigan P.A., McWilliam H., Valentin F., Wallace I.M., Wilm A., Lopez R., Thompson J.D., Gibson T.J. and Higgins D.G. (2007) Clustal W and Clustal X version 2.o. Bioinformatics 23, 2947-2948.

Maggioni R., Rogers A.D., Maclean N. and D'Incao F. (2001) Molecular phylogeny of Western Atlantic Farfantepenaeus and Litopenaeus shrimp based on mitochondrial $16 \mathrm{~S}$ partial sequences. Molecular Phylogenetics and Evolution 18, 66-73.

Marković O., Gökoğlu M., Petović S. and Mandić M. (2014) First record of the Northern brown shrimp, Farfantepenaeus aztecus (Ives, 1891)
(Crustacea: Decapoda: Penaeidae) in the South Adriatic Sea, Montenegro. Mediterranean Marine Science 15, 165-167.

Minos G., Kokokiris L., Imsiridou A., Karachle P. and Kapiris K. (2015) Notes on the distribution and biology of northern brown shrimp Farfantepenaeus aztecus (Ives, 1891) in the Eastern Mediterranean. Turkish Journal of Zoology 39, 1-7, doi: 10.3906/zoo-1403-19.

Nikolopoulou I., Baxevanis A.D., Kampouris T.E. and Abatzopoulos T.J. (2013) Farfantepenaeus aztecus (Ives, 1891) (Crustacea: Decapoda: Penaeidae) in N Aegean: first record in Greece by morphological and genetic features. Journal of Biological Research-Thessaloniki $20,367-375$.

NOAA (2013) Ecosystem status report for the Gulf of Mexico. NOAA Technical Memorandum NMFS-SEFSC-653. Available at: http://www. gulfcouncil.org/docs/Gulf\%20of\%2oMexico\%2oEcosystem\%2oStatus\% 20Report.pdf (accessed 21 January 2015).

Özcan T., Galil B.S., Bakir K. and Katagan T. (2006) The first record of the banana prawn Fenneropenaeus merguiensis (De Man, 1888) (Crustacea: Decapoda: Penaeidae) from the Mediterranean Sea. Aquatic Invasions 1, 286-288.

Özvarol Y. and Gökoğlu M. (2014) Biological data on northern brown shrimp Farfantepenaeus aztecus (Ives, 1891) (Decapoda: Penaeidae) in the Eastern Mediterranean Sea. In Stergiou K., Bobori D.C., Ekmekçi F.G., Gökoğlu M., Karachle P.K., Minos G., Özvarol Y., Salvarina I., Tarkan A.S. and Vilizzi L. (2014) New Fisheries-related data from the Mediterranean Sea (April 2014). Mediterranean Marine Science 15(1), 213-224.

Palumbi S.R., Martin A., Romano McMillan W.O., Stice L. and Grabowski G. (1991) A simple fool's guide to PCR. Honolulu: University of Hawaii Press.

Pérez-Farfante I. (1988) Illustrated key to Penaeoid Shrimps of commerce in the Americas. NOAA Technical Report, NMFS 64, 32 pp.

Platt A.R., Woodhall R.W. and George A.L. (2007) Improved DNA sequencing quality and efficiency using an optimized fast cycle sequencing protocol. Biotechniques 43, 58-62.

Stentiford G.D. and Lightner D.V. (2011) Cases of white spot disease (WSD) in European shrimp farms. Aquaculture 319, 302-306.

and

Tournier H. (1972) Conditions d'acclimatation des crevettes Penaeus kerathurus et $P$. japonicus dans les eaux du littoral languedocien. Science et Pêche, Bulletin de l'Institut des Pêches Maritimes, France 213, 1-13.

\section{Correspondence should be addressed to:}

G. Innocenti

Museo di Storia Naturale, Università di Firenze

via Romana 17, 50125 Firenze, Italy

email: gianna.innocenti@unifi.it 